\title{
Compressive Strength of Cement Mortar blended with Coconut Fibers and Human Hair
}

\author{
Ibrar Ahmad ${ }^{*}, 1,2$, Fayaz Ahmad ${ }^{2}$ Shah Room ${ }^{3}$, Zubair Abdullah $^{4}$, Muhammad Ihsan $^{5}$ \\ ${ }^{1}$ Assistant Professor, Department of Civil Engineering, Qurtuba University of Science and IT, D.I.Khan, Pakistan \\ ${ }^{2}$ Assistant Professor, Department of Civil Engineering, University of Engineering and Technology Peshawar, Pakistan \\ ${ }^{3}$ Lecturer, Department of Civil Engineering, City University of Science and IT, Pakistan \\ ${ }^{4}$ Lecturer, Department of Civil Engineering, Qurtuba University of Science and IT, D.I.Khan, Pakistan \\ ${ }^{5}$ Assistant Resident Engineer, East Consultants D.I.Khan, Pakistan
}

\author{
Article history: \\ Received: 25 August, 2016 \\ Accepted: 30 September, 2016 \\ Online: 25 October 2016
}

Keywords:

Fibers

Pollution

Blended Mortar

\begin{abstract}
A B S T R A C T
Mortar is used all over the world for construction purpose. It consists of cement paste and fine aggregates and admixtures if required are also incorporated to modify some of its properties. In this study coconut fibers and human hair were used as an additive materials in the mortar and its effects on compressive strength of the mortar were investigated. Coconut fibers and human hair are waste materials which are produced in millions of tons every year which create not only biodegradability problems but also cause pollution. Coconut fibers and human hair were used as additive materials in mortar in 2, 4 and $6 \%$ to prepare blended mortar. Mortar samples of coconut fibers and human hair were prepared and compared with each other and control samples. Cement to sand ratio was kept 1:3 with water cement ratio of 0.6 for all mixes. Cubes having dimensions of $2 \times 2 \times 2$ inches were used in this project. All the mixes were cured at normal room temperature for 3,7 and 28 days. Results revealed that mix with 4\% coconut fibers showed higher compressive strength at 3 days and 6\% higher compressive strength at 28 days. With increase of coconut fibers compressive strength increased. However, mortar with human hair initially shows higher strength when $2 \%$ was incorporated but with increasing percentage of human hair, strength was reduced. With addition of mix fibers i.e. coconut fibers and human hair into the mix, the compressive strength initially increased at $3^{\text {rd }}$ day of curing, showing higher compressive strength at 3 days for all percentages of mix compare to reference mortar, however with further increase of percentage of mix fibers into the mortar, the compressive strength was reduced showing lowest compressive strength at $28^{\text {th }}$ days for $4 \%$ of mix fibers i.e. coconut fibers and human hair.
\end{abstract}

\section{Introduction}

Several problems have evolved because of increasing temperature on the use of mortar and concrete in recent few years where it has sufficiently threaten the performance of mortar and concrete. Similarly some non-biodegradable wastes have also increased leading to un-hygienic conditions. Efforts are needed to educate public on the importance of fibers and its consequences both in short run and long run [1]. Fibers are waste materials which are obtained from various sources and hence treated as waste material because it is a major threat to environment.

\footnotetext{
*Ibrar Ahmad, Qurtuba University of science \& IT, D.I Khan

Contact No+923139470539 \& Email ibrarkhattak69@gmail.com
}

www.astesj.com

https://dx.doi.org/10.25046/aj010401
Coconut fibers are long thread like structures which are obtained from outer shells of coconut. These fibers are very strong and tough. Coconut fibers have the highest toughness amongst natural fibers. Coconut fiber shows a great resistance to fungi attack. Coconut fibers act as excellent insulators against heat and sound. Coconut fibers are light in weight. Coconut fibers acts as a fire resistant material. Coconut fibers do not contain any kind of hazardous materials and so can easily be handled. They have rough structure and so form proper and strong bond with concrete. They have water absorption ability. Similarly human hair is also waste materials and as it is a non-biodegradable therefore it is also an environmental hazard, therefore its use in mortar can not only minimizes its environmental hazards but can also play an 


\section{Ahmad et al. / Advances in Science, Technology and Engineering Systems Journal Vol. 1, No. 4, 1-4 (2016)}

important role to increase compressive strength of mortar. It is easily and cheaply available throughout the world thus it can be used in concrete as the cheapest ingredient. It has got good tensile strength therefore it can play an important role to increase strength of mortar. Specific gravity ranges from 1.2 to 1.35 [2]. It is light in weight so mortar made of it will also be light. Density of coconut fibers ranges from $0.67-1 \mathrm{~g} / \mathrm{cm}^{3}$ [3]. Fibers used in mortar and concrete are environmental friendly and are also economical because these fibers are locally available [4].

\section{Research Significance}

Due to global warming the ozone layer is depleted due to which the temperature of earth is constantly increasing which has threaten the performance of concrete used in our structures. Year 2009 was declared as international year of natural fiber by United Nation General Assembly in order to highlight its importance to world and to make the world aware of its consequences [5]. More than 500,000 ton coconut fibers are produced throughout the world including Sri Lanka, Philippines, Nepal and Indonesia. Pakistan is also amongst those countries where sufficient quantity of coconut is cultivated in coastal areas [5]. Cementious materials thus reducing environmental hazards along with increment of better concrete with useful properties. In present study mortar cubes were made with different percentages of coconut fibers and human hair fibers and cured up to 28 days. Compressive strength tests were carried out at different period to observe the performance of fiber reinforced mortar.

\section{Physical Properties of Fibers}

\subsection{Physical Properties of Coconut Fibers}

1. Length: length of coconut fibers usually ranges from $27 \mathrm{~cm}$ to $35 \mathrm{~cm}$.

2. Diameter: Diameter of coconut fiber is almost same and ranges from 12-25 micron.

3. Density: Density of coconut fibers ranges from $0.67-1 \mathrm{~g} / \mathrm{cm}^{3}$ [3].

4. Strength: Coconut fibers has the ability to take additional strain of 4-6 times greater than other fibers.

5. Specific gravity: Specific gravity ranges from 1.2-1.35 [2].

\subsection{Physical Properties of Human Hair}

1. Lengthening of up to $5 \%$, hair is elastic

2. Hair is the strongest, withstanding a weight of 100 grams and an elongation of $55 \%$

3. Human hair has about $65-95 \%$ of its weight in proteins, more $32 \%$ of water, lipid pigments and other components. Chemically, about $80 \%$ of human hair is formed by a protein known as keratin [6].

4. Keratin has special affinity for water. This absorption depends on the air relative humidity rate and greatly interferes on all the proprieties of the hair, as: stretching ability, diameter and internal viscosity of the fibers.

5. Friction is higher in wet than in dry hair.

6. Hair tends also to be pervious to water in its liquid form. This absorption is followed by a swelling in the hair, with $15-10 \%$ increase in its thread diameter and $0.5-1.0 \%$ in its length.

7. It has a high tensile strength which is equal to that of a copper wire with similar diameter [7].
8. Human hair is nonhazardous but it is non bio degradable thus causing environmental threat. Every use of human hair does not reduce the human hair waste because, in some uses, the disposal of the hair after use can bring it back into waste streams. For example, even though wigs and hair extensions use human hair at large scale, the hair is not consumed during use, after which it is again thrown away in the solid waste.

9. The hair neither decay nor leave it intact for safe reuse or recycling. There are the applications that involve either contamination of the hair with toxic chemical or irreversible blending with certain non-biodegradable or ecologically unsafe materials. Hair contaminated with toxic organic pollutants is one such case. Other such use would be human hair composites with non-biodegradable resin. Recycling or safe disposal of these products require further processing to remove the specific contamination or separation of the other materials. For example, hair composites with nonbiodegradable resin would need a method to separate the two materials or a method for safe decomposition such as combustion at very high temperatures to ensure safe destruction.

\section{Experimental Program}

The experimental was planned to find out the compressive strength of mortars using coconut fibers and human hair fibers in addition to cement as a waste materials. Fibers addition at various percentage levels were used in this research to investigate and observe the effects of different levels of fibers in mortar in contributing the compressive strength of mortars at various ages of curing.

\subsection{Cement}

ASTM Type-I Portland Cement conforming to ASTM C-150 was used as binding material. The physical properties and chemical compositions of OPC are given in Table-1 and Table-2 respectively.

\begin{tabular}{|c|c|}
\hline \multicolumn{2}{|c|}{ Table 1: Physical Properties of Cement } \\
\hline Physical properties & $\begin{array}{c}\text { ASTM Type-1 } \\
\text { Cement }\end{array}$ \\
\hline $\begin{array}{c}\text { \%age fineness } \\
\text { (Passing \#200 sieve) }\end{array}$ & 93 \\
\hline Initial setting time & 30 minutes \\
\hline Final setting time & 45 minutes \\
\hline $\begin{array}{c}\text { 3 days Compressive } \\
\text { Strength }\end{array}$ & $2233.581 \mathrm{Psi}$ \\
\hline $\begin{array}{c}7 \text { days Compressive } \\
\text { Strength }\end{array}$ & $2886.251 \mathrm{Psi}$ \\
\hline $\begin{array}{c}\text { 28 days Compressive } \\
\text { Strength }\end{array}$ & 4380.14 Psi \\
\hline Specific gravity & 3.15 \\
\hline
\end{tabular}

\begin{tabular}{|c|c|}
\hline \multicolumn{2}{|c|}{$\begin{array}{c}\text { Table 2: Chemical } \\
\text { Composition of Cherat } \\
\text { Cement }\end{array}$} \\
\hline Oxides & $\begin{array}{c}\text { Percentage } \\
\text { (\%) }\end{array}$ \\
\hline $\mathrm{Al}_{2} \mathrm{O}_{3}$ & 21.24 \\
\hline $\mathrm{SiO}_{2}$ & 5.56 \\
\hline $\mathrm{Fe}_{2} \mathrm{O}_{3}$ & 3.24 \\
\hline $\mathrm{CaO}$ & 65.53 \\
\hline $\mathrm{MgO}$ & 0.93 \\
\hline $\mathrm{SO}$ & 2.55 \\
\hline $\mathrm{LOI}$ & 1.24 \\
\hline $\mathrm{IR}$ & 0.64 \\
\hline Free Lime & 0.55 \\
\hline
\end{tabular}

\subsection{Sand}

Locally available natural sand passing through $4.75 \mathrm{~mm}$ sieve and retained on $0.015 \mathrm{~mm}$ sieve was used in this research. Gradation of this sand is given in Table-3. 
I. Ahmad et al. / Advances in Science, Technology and Engineering Systems Journal Vol. 1, No. 4, 1-4 (2016)

Table 3: Sieve Analysis of Sand

\begin{tabular}{|c|c|c|c|c|c|}
\hline $\begin{array}{c}\text { Sieve } \\
\text { No }\end{array}$ & $\begin{array}{c}\text { Sieve } \\
\text { Size } \\
(\mathbf{m m})\end{array}$ & $\begin{array}{c}\text { Retained } \\
\text { Mass } \mathbf{( g )}\end{array}$ & $\begin{array}{c}\text { Retained } \\
\mathbf{( \% )}\end{array}$ & $\begin{array}{c}\text { Passing } \\
\mathbf{( \% )}\end{array}$ & $\begin{array}{c}\text { Cumulative } \\
\text { percentage } \\
\text { retained }\end{array}$ \\
\hline 8 & 2.36 & 12.91 & 4.30 & 95.60 & 4.30 \\
\hline 16 & 1.18 & 9.51 & 3.17 & 92.53 & 7.47 \\
\hline 30 & 0.6 & 50.19 & 16.73 & 75.80 & 24.20 \\
\hline 50 & 0.3 & 111.0 & 37 & 38.80 & 61.20 \\
\hline 100 & 0.15 & 77.90 & 25.90 & 12.80 & 87.16 \\
\hline 200 & 0.075 & 28.57 & 9.50 & 3.30 & 96.6 \\
\hline Pan & & 9.92 & & & 100 \\
\hline
\end{tabular}

Fineness Modulus of sand is calculated as

$$
F . M=\frac{(4.30+7.47+24.20+61.20+87.16+96.60)}{=2.80} 100
$$

\subsection{Mix Proportioning}

Four different mix proportions of fiber cement mortar cubes $(0 \%, 2 \% .4 \%$ and $6 \%)$ were prepared having size of $50 \mathrm{~mm} \times 50$ $\mathrm{mm} \times 50 \mathrm{~mm}$. Cement to sand ratio was kept as 1:3 as a reference mortar for comparing the properties of mortar in addition of fibers, while the water to cement ratio was kept as 0.6. The fiber mortar means the mortar made by using cement and fibers as an additive material with sand and water. Details of mix proportion and materials are shown in Table 3.

Table 4: Mix Proportioning

\begin{tabular}{|c|c|c|}
\hline S. No. & Material & Quantity \\
\hline 1 & Fiber Length & $50 \mathrm{~mm}$ \\
\hline 2 & Cement & 500 gram \\
\hline 3 & Sand & 1500 gram \\
\hline 4 & w/c & 0.6 \\
\hline 5 & Water & 300 \\
\hline
\end{tabular}

\subsection{Washing of human hair}

After sorting, the hair was washed using water with shampoo because washing of hair with only water is harmful to hair. It particularly accentuates the negative effects of sunlight, hair's other great enemy. Melanin degradation is encouraged and sun linked discoloration intensifies. Keratin itself is altered, making the hair fragile and easily damaged [8].

The hair was then dried under sun. After drying, the hair was used in cement mortar.

\subsection{Curing Environment and Testing}

Total of 140 mortar specimens were casted in the laboratory. After casting, the specimens were kept at $27^{\circ} \mathrm{C}$ temperature and $90 \%$ relative humidity for 24 hours. After removal from moulds, all the specimens were cured in water at room temperature for 3, 7 and 28 days. After specific exposure period, specimen was tested for compressive strength in accordance with test procedure (ASTM C109-87) [9].

\section{Compressive Strength Test Results and Discussion}

Cubes for all mortars were tested for compressive strength at 3,7 and 28 days. The results for mortar MC, MH, MCH are shown in Table 4.
Table 5: Average Compressive Strength of Mortar Mixes

\begin{tabular}{|c|c|c|c|}
\hline \multirow{2}{*}{ Mortar Type } & \multicolumn{3}{|c|}{ Average Compressive Strength (Psi) } \\
\cline { 2 - 4 } & 3 days & 7 days & 28 days \\
\hline MC-0 & 843 & 1342 & 2315 \\
\hline MH-0 & 843 & 1342 & 2315 \\
\hline MCH-0 & 843 & 1342 & 2315 \\
\hline MC-2 & 1293 & 2150 & 2822 \\
\hline MH-2 & 1391 & 1506 & 2114 \\
\hline MCH-2 & 944 & 1471 & 2080 \\
\hline MC-4 & 1519 & 2334 & 3121 \\
\hline MH-4 & 745 & 1136 & 1523 \\
\hline MCH-4 & 908 & 1103 & 1530 \\
\hline MC-6 & 1439 & 2870 & 3270 \\
\hline MH-6 & 513 & 778 & 1209 \\
\hline MCH-6 & 1161 & 1583 & 1902 \\
\hline
\end{tabular}

Figure 1 shows that with addition of coconut fibers into the mix, the compressive strength increased. However with further increase of percentage of coconut fibers into the mix, the compressive strength increased at 7 days.

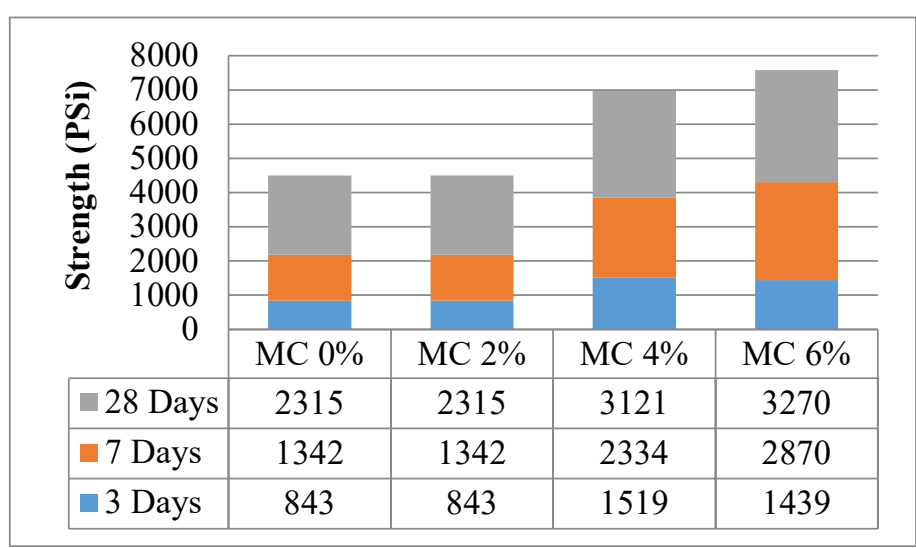

Figure 1: Compressive Test Result

However at 3 day of curing there was no difference in compressive strength of mortar between $4 \%$ and $6 \%$ of curing while at 28 day the compressive strength at $4 \%$ was higher than $2 \%$ and lower than $6 \%$ of coconut fibers.

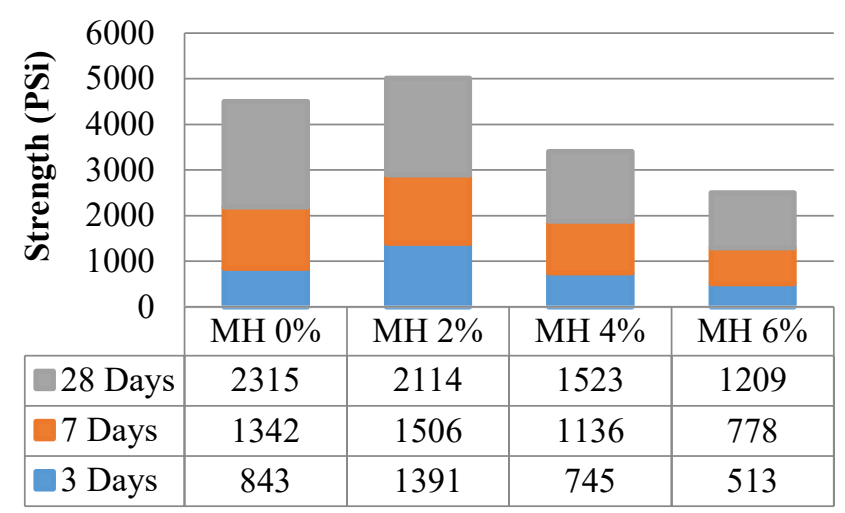

Figure 2: Compressive Test Result

Figure 2 shows that with addition of $2 \%$ human hair in the mix, the compressive strength increased. However with further increase of human hair beyond $2 \%$, the compressive strength decreased progressively with the lowest values observed at the highest rate of $6 \%$ at all days of curing. 


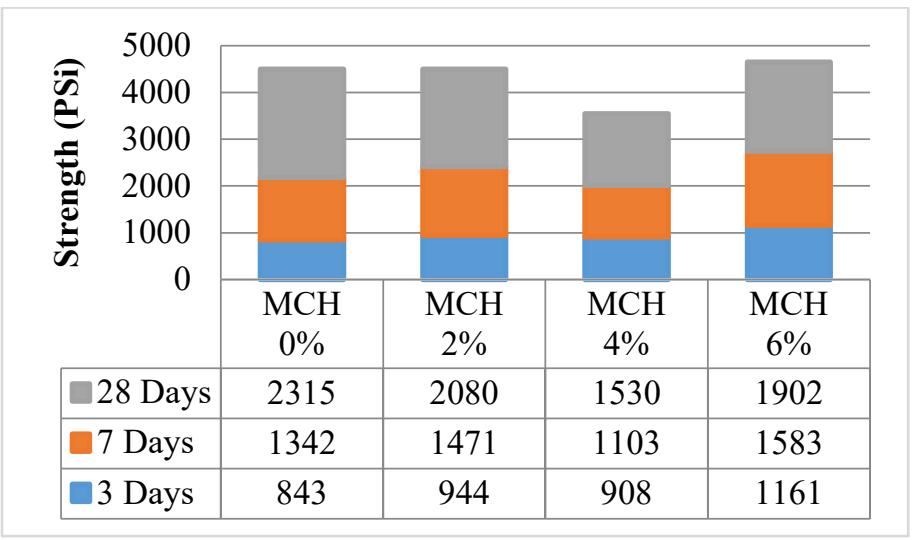

Figure 3: Compressive Test Result

Figure 3 shows that with addition of $2 \%$ mixed fibers (coconut fibers and human hair) into the mix, the compressive strength increased at 3, 7 and 28 days of curing. However with further increase of mixed fibers into the mix, the compressive strength is decreased progressively with the lowest value of $4 \%$ of mix fibers at $7^{\text {th }}$ and $28^{\text {th }}$ days of curing but compressive strength was higher at $3^{\text {rd }}$ day for $4 \%$ of mix fibers than $0 \%$ at $3^{\text {rd }}$ day of curing, while the compressive of $6 \%$ is increased at 3 day and 7 days of curing however at 28 day of curing, the compressive strength was lower for $6 \%$ than $2 \%$ of mixed fibers.

\section{Conclusions}

This research work is further extension of the use of blended materials under the effect of using coconut fibers and human hair so that strength can be increased and also the adverse effects of these wastes materials can be reduced to keep our environment clean from the effects of such wastes.

- Coconut fibers of $4 \%$ into the mix gave high 3 days strength and $6 \%$ gave high compressive strength at 28 days of curing at room temperature.

- By increasing the percentage of coconut fibers the strength of mortar increased at all days of curing.

- The use of human hair up to $2 \%$ initially gave high strength. However with further increasing the percentage of human hair into the mix showed reduction in compressive strength of mortar at all days of curing.

- Addition of $6 \%$ of mix fibers (coconut fibers and human hair) into the cement mortar showed higher compressive strength at $3^{\text {rd }}$ day than $2 \%$ and $4 \%$, while compressive strength of mortar was found higher for $2 \%$ at $28^{\text {th }}$ day than compressive strength of mortar for $4 \%$ and $6 \%$ of mix fibers.

\section{References}

[1] J. P. C.-G. L.A. Pereira de Oliveira, "Physical and mechanical behaviour of recycled PET fibre reinforced mortar," Construction and Building Materials, 25: $1712-1717$ (2011).

[2] M.-A. Arsène, H. Savastano Jr, S. M. Allameh, K. Ghavami, and W. O. Soboyejo, "Cementitious composites reinforced with vegetable fibers," in Anais da 1st Inter American Conference on Nonconventional Materials and Technologies in the Ecoconstruction and Infrastructure. João Pessoa-PB, 143-, 2003.

[3] R. D. T. F. e. al., "Free, restrained and drying shrinkage of cement mortar composites reinforced with vegetable fibre," Cement \& Concrete Composites, 27:537-546 (2005).

[4] M. Ali, "Coconut Fibre - A Versatile Material and its Applications in Engineering," presented at the Second International Conference on Sustainable Construction Materials and Technologies, Italy, 2010.
[5] M. A, "Coconut Fiber -A Versatile Material and its Applications in Engineering," Civil Engineering and Construction Technology, 2: 189-197 (2010).

[6] I. J. Kaplin, Schwan, A., and Zahn, H., "Effects of Cosmetic Treatments on the Ultrastructure of Hair," Cosmet. Toiletries, 97: 22-26 (1982).

[7] J. N. A. a. S. Ahmad, "The Effect of Randomly Oriented Hair Fiber on Mechanical Properties of Fly-Ash Based Hollow Block for Low Height Masonry Structures," Asian J. Civil Engg. (Building And Housing) 10: 221228 (2009).

[8] A. Fisk. The Human Hair Trade. Available Online at: http://adrianfisk.photoshelter.com/portfolio/G0000BEXCMmo5TRo

[9] J. H. Matthys, Masonary: Components to Assemblages, 1990. 